\title{
Pengaruh Penggunaan SIA dan TI Terhadap Kinerja Individual dengan Kemampuan Teknik Pemakai sebagai Pemoderasi
}

\author{
Putu Maya Fransisca Rahayu ${ }^{1}$ \\ I Dewa Gede Dharma Suputra²
}

\author{
${ }^{1,2}$ Fakultas Ekonomi dan Bisnis Universitas Udayana (Unud), Bali, Indonesia \\ e-mail: fransiscamaya53@yahoo.com
}

\begin{abstract}
ABSTRAK
Penelitian ini dilakukan pada 40 koperasi simpan pinjam di Kota Denpasar dengan responden sebanyak 93 orang. Teknik penentuan sampel yang digunakan adalah purposive sampling dengan metode kuesioner. Dengan menggunakan teknik analisis Moderating Regression Analysis (MRA) ditemukan hasil yang membuktikan bahwa variabel penggunaan SIA berpengaruh positif dan tidak signifikan pada kinerja individual dan TI berpengaruh positif pada kinerja individual. Variabel kemampuan teknik pemakai dapat memoderasi pengaruh penggunaan SIA pada kinerja individual dan pada hasil selanjutnya, variabel kemampuan teknik pemakai tidak dapat memoderasi pengaruh TI pada kinerja individual pada koperasi simpan pinjam di Kota Denpasar.

Kata kunci: Kemampuan teknik pemakai, penggunaan SIA, penggunaan TI, kinerja individual.
\end{abstract}

\begin{abstract}
The study at 40 cooperation in the city of denpasar with 93 respondents. The technique of determination sampling method is used purposive with the questionnaire. The analysis using moderating regression analysis technique ( $\mathrm{mra}$ ) found results that prove the variable the use of accounting information system has positive effects and not significant on the performance of individual and information technology had a positive impact on the performance of individual. The ability of users variable technique can be moderating the influence of the use of accounting information system on the performance of individual and on the next outcome, technique variable the ability of users cannot be moderating the influence of information technology on the performance of individually on cooperation in Denpasar.

Keywords: technical ability, the use of accounting information system, the use of information technology, individual performance.
\end{abstract}

\section{PENDAHULUAN}

Lembaga keuangan sebagai perantara bagi masyarakat yang menyimpan uang dengan masyarakat yang membutuhkan uang sangat berperan penting terhadap pertumbuhan perekonomian suatu negara. Koperasi merupakan salah satu lembaga keuangan bukan bank yang sesuai dengan kepribadian bangsa Indonesia. 
Putu Maya Fransisca Rahayu dan I Dewa Gede Dharma Suputra. Pengaruh...

Seiring dengan perkembangan koperasi dewasa ini tidak lepas dari persaingan antar sesama koperasi maupun lembaga sejenis lainnya. Hal tersebut berpengaruh terhadap kondisi koperasi saat ini untuk mampu bersaing dengan menunjukkan keunggulan kompetitifnya. Informasi keuangan sebuah organisasi merupakan salah satu hal yang penting untuk dapat memenangkan persaingan bisnis (Nabizadeh, 2014).

Informasi didefenisikan sebagai data yang telah diubah menjadi konteks yang bermanfaat dan berarti bagi pemakai tertentu (O’Brien, 2006). Informasi merupakan serangkaian data yang telah diolah sehingga memiliki makna yang berguna untuk mengambil sebuah keputusan yang efektif. Informasi yang berkualitas haruslah relevan, akurat, lengkap, tepat waktu, mudah dipahami, dapat diverifikasi, dan dapat diakses sangat dibutuhkan oleh sebuah organisasi agar dapat mengambil sebuah keputusan (Romney dan Steinhart, 2014). Sistem informasi akuntansi adalah serangkaian sistem yang memiliki unsur dan komponen tertentu agar dapat menginput, mengolah, serta menyimpan data keuangan guna menghasilkan informasi yang dibutuhkan untuk mempermudah proses kegiatan operasional bisnis. Daya saing dari perusahaan bisa dilihat dari bagaimana sistem informasi keuangan memberikan informasi yang tepat berupa informasi keuangan bagi manajemen (Alsarayreh, et al, 2011).

Sumber Daya Manusia (SDM) merupakan salah satu aset utama untuk meningkatkan profitabilitas. Sistem informasi akuntansi tidak akan berfungsi dengan baik jika tidak didukung oleh SDM. Karyawan sebagai salah satu SDM di dalam organisasi berperan penting untuk kelancaran usaha, oleh karena itu 
karyawan harus mampu mengelola dan menggunakan sistem informasi akuntansi di dalam perusahaan secara tepat. Keberhasilan organisasi dalam mencapai sebuah tujuan bergantung pada kinerja karyawan.

Sebuah sistem yang dapat memberikan dampak positif terhadap penggunanya merupakan sistem yang efektif. Setelah sistem dioperasikan selama beberapa waktu, perlu dilakukan pengamatan lebih lanjut untuk mengetahui sejauh mana sistem tersebut mencapai sasaran yang telah ditetapkan dan untuk mengetahui jika sistem dapat digunakan kembali serta melanjutkan proses pengoperasian, dan apabila diketahui sistem dapat dilanjutkan maka perlu dipertimbangkan untuk melakukan modifikasi ataua tidak untuk dapat mencapai sasaran yang ditetapkan.

Penggunaan sistem informasi diyakini Technology Acceptance Model (TAM) akan meningkatkan kinerja individu atau organisasi (Gupta et al., 2007). Pemakaian sistem informasi akuntansi yang efektif dapat dilihat dari penggunaan dan pemanfaatan komputer di dalam perusahaan. Semakin mahir penggunanya, maka penerapan SIA akan semakin efektif karena pemahaman yang cukup dan kompeten oleh pengguna. Tidak maksimalnya penerapan teknologi informasi oleh individu pengguna sistem informasi dapat mengakibatkan penurunan kinerja. Dengan meningkatkan kinerja pemakainya maka penggunaan teknologi informasi dapat dioptimalkan akan tetapi hal tersebut tidak berarti bahwa setiap individu dapat merasakan manfaatnya dan menerima secara positif keberadaan teknologi tersebut (Thompson, et al., 1991).

Sebelum melakukan penerapan teknologi informasi, pelaksanaan 
Putu Maya Fransisca Rahayu dan I Dewa Gede Dharma Suputra. Pengaruh...

pencatatan, pemrosesan dan penggunaan informasi dilakukan secara manual. Persaingan dalam era globalisasi yang semakin ketat seiring dengan kemajuan teknologi mamaksa organisasi untuk beralih dari sistem manual menjadi sistem teknologi informasi berbasis komputer. Para manajer serta pengambil keputusan dalam perusahaan memerlukan bantuan teknologi informasi dalam mengambil keputusan untuk meramal situasi dan kondisi di masa yang akan datang dalam keperluan bisnis.

Dasar untuk memperoleh keunggulan kompetitif dalam perusahaan adalah kemampuan untuk mengelola informasi secara efektif (Maamir dan Yadnyana, 2012). Pengguna komputer dituntut untuk meningkatkan kemempuannya dan kemahirannya agar dapat menggunakan sistem informasi akuntansi di dalam perusahaan dengan tepat.

Penggunaan sistem informasi akuntansi mengharuskan pemakainya untuk menggunakan sistem untuk mencapai tujuan perusahaan dengan memanfaatkan teknologi informasi. Hasil penelitian oleh Darmini dan Putra (2008) menunjukkan hasil positif yang signifikan antara pemanfaatan teknologi informasi dan kepercayaan sistem informasi yang baru terhadap kinerja individual pada BPR di Kabupaten Tabanan. Implementasi sistem informasi memoderasi pengaruh produktivitas tenaga kerja terhadap jumlah keluhan, dan tidak berpengaruh terhadap tingkat keberhasilan penerimaan barang (Christianto, dkk. 2007). Pemakaian sistem informasi akuntansi sangat berpengaruh terhadap kinerja perusahaan yang terdaftar dalam Dubai Financial Market (DFM) namun tidak berpengaruh terhadap kinerja manajemen (Soudani, 2012). Suatu sistem yang 
dapat memberikan nilai tambah bagi perusahaan dapat dikatakan sebagai sistem informasi yang efektif. Perilaku pemakai yang profesional dapat menjadi nilai tambah bagi perusahaan sehingga dapat memberikan pengaruh yang positif terhadap pemakainya dan sistem menjadi sangat efektif untuk digunakan.

Berdasarkan uraian diatas, hal ini memotivasi penulis untuk meneliti kembali dengan mengambil judul "Pengaruh Penggunaan Sistem Informasi Akuntansi dan Teknologi Informasi Terhadap Kinerja Individual dengan Kemampuan Teknik Pemakai sebagai Pemoderasi pada Koperasi di Kota Denpasar". Penelitian ini akan dilakukan pada Koperasi simpan pinjam di Kota Denpasar dengan pertimbangan bahwa Denpasar merupakan salah satu kota yang memiliki jumlah koperasi terbanyak di Provinsi Bali. Adapun rumusan masalah penelitian ini adalah sebagai berikut : apakah penggunaan sistem informasi akuntansi berpengaruh positif terhadap kinerja individual pada koperasi simpan pinjam di kota Denpasar. Apakah penggunaan teknologi informasi akuntansi berpengaruh positif terhadap kinerja individual pada koperasi simpan pinjam di kota Denpasar. Apakah kemampuan teknik pemakai memoderasi pengaruh penggunaan sistem informasi akuntansi terhadap kinerja individual pada koperasi simpan pinjam di kota Denpasar. Apakah kemampuan teknik pemakai memoderasi pengaruh penggunaan teknologi informasi akuntansi terhadap kinerja individual pada koperasi simpan pinjam di kota Denpasar.

Hasil penelitian ini dapat menambah pengetahuan mengenai pengaruh penggunaan sistem informasi akuntansi dan teknologi informasi pada kinerja individual dengan dimoderasi oleh kemampuan teknik pemakai sistem informasi 
Putu Maya Fransisca Rahayu dan I Dewa Gede Dharma Suputra. Pengaruh...

akuntansi. Bagi perusahaan dapat dijadikan referensi untuk mengambil keputusan mengenai sistem informasi akuntansi dan dapat dijadikan referensi untuk penelitian selanjutnya, khususnya yang berkaitan dengan sistem informasi akuntansi.

Technology Acceptance Model (TAM) oleh Davis (1989) yang dikembangkan oleh Fishbe dan Ajzen (1975) menawarkan sebuah teori untuk dijadikan landasan agar mendapatkan pemahaman mengenai perilaku pengguna sistem informasi dalam menerima dan menggunakan sebuah sistem. Model ini menunjukkan bahwa jika terdapat sebuah teknologi baru maka penggunanya akan dihadapkan pada faktor-faktor yang mempengaruhi cara penggunaan teknologi tersebut.

Technology Acceptance Model (TAM) berteori bahwa terdapat dua faktor yang menentukan penggunaan sistem atau teknologi, yaitu persepsi kemudahan penggunaan (Perceived Ease of Use) yang didefinisikan sebagai tingkat kepercayaan seseorang terhadap penggunaan teknologi yang meyakini dirinya bebas dari upaya atau lebih mudah dalam menyelesaikan suatu pekerjaan dan persepsi kemanfaatan (Perceived Usefulness) yang didefinisikan sebagai tingkat kepercayaan seseorang terhadap penggunaan teknologi yang dapat meningkatkan kinerjanya (Venkatesh,et al, 2003). Technology Acceptance Model (TAM) meyakini bahwa kinerja individu maupun perusahaan akan meningkat seiring dengan penggunaan sistem informasi serta akan mempermudah pemakai sistem untuk menyelesaikan pekerjaannya (Gupta,et al, 2007).

Teknologi Informasi (TI) merupakan sub sistem atau bagian dari sistem 
informasi (Jogiyanto, 2000:3). Menurut Information Technology Training Package ICA99 dalam Supriyanto (2005:6), teknologi informasi adalah pengembangan teknologi dan aplikasi komputer serta teknologi berbasis komunikasi untuk memproses, menyajikan, mengolah data dan informasi. Termasuk juga dengan pengembangan software komputer, pembuatan hardware dan komponen komputer, serta berbagai jasa yang berhubungan dengan komputer. Menurut Turban dan Potter (2006:49), teknologi informasi didefinisikan sebagai kumpulan sumber daya informasi perusahaan, para penggunanya, serta manajemen yang menjalankannya meliputi infrastruktur TI dan semua sistem informasi lainnya dalam perusahaan.

Sistem informasi akuntansi merupakan sebuah elemen dalam organisasi yang menyediakan informasi bagi pemakai informasi dengan pencatatan transaksi keuangan. Berbagai informasi keuangan dalam perusahaan akan lebih mudah diakses dan diketahui oleh para pengguna tertentu dengan adanya penerapan dan penggunaan sistem informasi akuntansi yang efektif. Dengan penerapan sistem informasi akuntansi dalam perusahaan akan memberikan kemudahan untuk para manajer dalam meningkatkan efisiensi dan efektivitas pengambilan keputusan sehingga perusahaan akan memiliki keunggulan kompetitif. Sistem informasi merupakan faktor penting untuk mencapai sebuah kinerja yang lebih besar salah satunya adalah pengambilan keputusan (Al-eqab and Adel, 2013).

Sistem informasi berbasis komputer adalah sistem informasi yang memanfaatkan komputer untuk memproses segala bentuk transaksi keuangan dan non-keuangan serta sebagai alat bantu dalam mengambil keputusan pada konteks 
Putu Maya Fransisca Rahayu dan I Dewa Gede Dharma Suputra. Pengaruh...

koordinasi dan pengendalian kegiatan didalam organisasi.

Penggunaan sistem informasi didefinisikan sebagai perilaku seorang individu yang menggunakan sistem informasi karena adanya manfaat yang akan diperoleh untuk membantu dalam menyelesaikan pekerjaannya. Sebuah sistem informasi akuntansi diharapkan dapat menghasilkan sebuah informasi yang berupa laporan keuangan maupun non-keuangan yang berisikan sekumpulan data sesuai dengan kebutuhan pengguna sistem.

Pengimplementasian dengan penggunaan sistem informasi yang tepat dalam sebuah perusahaan dapat dilihat dari kemudahaan para pengguna sistem dalam mengidentifikasi, mengakses dan menginterpretasikan data tersebut. Data yang terdapat di dalam sebuah sistem informasi merupakan data yang terintegrasi dari seluruh unit yang ada di perusahaan sehingga dapat bermanfaat dan berguna sesuai dengan kebutuhan dan tugas pemakai informasi (Jumaili, 2005).

Kemampuan penggunaan komputer yang semakin berkembang akan merubah cara pandang karyawan dalam berinteraksi dengan komputer. Hal ini akan menggeser posisi pemakai atau karyawan sebagai user menjadi end user computing. End User Computing (EUC) adalah sistem informasi berbasis komputer yang mendukung aplikasi operasional serta manajerial and end-user secara langsung dan merupakan salah satu metode pengembangan sistem berbasis komputer yang dilakukan oleh pemakai (user). Pemakai yang mengembangkan aplikasinya sendiri dari pada bergantung kepada spesialis informasi banyak kita temui di era saat ini, pendekatan ini lah yang dinamakan dengan EUC. Kemampuan karyawan pada lingkungan sistem informasi yang diimplementasikan 
akan mempengaruhi tingkat penerimaan karyawan terhadap penerapan suatu sistem informasi dalam perusahaan (Kustono, 2011).

Mengetahui tingkat pencapaian tujuan suatu organisasi, pihak yang berkepentingan harus mengetahui dan mengkonfirmasi kondisi kinerja individual di dalam organisaasi (George et al., 2012). Kinerja individu dapat menunjukan dampak positif dan dampak negatif dari sebuah keputusan atau kebijakan operasional. Keberhasilan sistem informasi suatu perusahaan bergantung kepada bagaimana sistem itu dijalankan, kemudahan sistem itu bagi para pemakainya, dan pemanfaatan teknologi yang digunakan (Goodhue dan Thompson, 2012). Sistem informasi akuntansi yang digunakan dapat memonitoring dan membantu proses kinerja sehingga dapat meningkatkan kualitas pelayanan pada lembaga tersebut (Damayanti, 2012).

Koperasi Simpan Pinjam adalah salah satu jasa keuangan yang menyediakan layanan berupa penghimpunan dana dalam bentuk tabungan dan deposito (Latifah, 2006). Koperasi simpan pinjam memegang peran penting sebagai jasa alternatif untuk usha mikro, kecil dan menengah. Salah satu tujuan koperasi simpan pinjam adalah untuk mendidik anggotanya agar lebih memahami berbagai hal tentang koperasi dan mengajarkan cara untuk hidup berhemat dan sejahtera.

Pencapaian sebuah target dari kumpulan komponen sumber daya yang diatur untuk memproses, mengumpulkan dan menyimpan data elektronik yang kemudian dapat diubah menjadi sebuah informasi sehingga dapat memberikan laporan yang diperlukan sesuai dengan kebutuhan secara tepat waktu dan berkualitas merupak gambaran dari penggunaan sistem informasi. Technology 
Putu Maya Fransisca Rahayu dan I Dewa Gede Dharma Suputra. Pengaruh...

Acceptance Model (TAM) meyakini bahwa kinerja individu maupun perusahaan akan meningkat seiring dengan penggunaan sistem informasi serta akan mempermudah pemakai sistem untuk menyelesaikan pekerjaannya (Gupta,et al, 2007).

Ismail dan King (2007) menyatakan bahwa sistem informasi akuntansi dapat melancarkan pengerjaan tugas para pegawai dalam perusahaan karena dengan menghubungkan informasi dari atasan dan bawahan dapat membantu mereka untuk mencapai tujuan mereka. Marlinawati dan Suaryana (2012) menyatakan bahwa efektivitas sistem informasi akuntansi berpengaruh terhadap kinerja individual. Marlita dan Dharmadiaksa (2014) menyatakan bahwa efektifitas sistem informasi akuntansi berpengaruh positif terhadap kinerja karyawan. Hasil penelitian oleh Suratini (2015) menunjukkan pengaruh positif antara efektivitas sistem informasi akuntansi dengan kinerja individual. Berdasarkan uraian tersebut, maka hipotesis dirumuskan sebagai berikut :

$\mathrm{H}_{1}$ : Penggunaan sistem informasi akuntansi berpengaruh positif terhadap kinerja individual.

Suatu sistem informasi yang baik hendaknya memberikan kemudahan kepada para pemakai utamanya pada kegiatan pengidentifikasian data, mengakses data, maupun menginterpretasikannya dalam kegiatan penyelesaian tugas. Apabila dalam tubuh organisasi atau perusahaan memiliki fasilitas pendukung dalam jumlah yang mencukupi, maka hal itu akan memberikan kemudahan bagi para pemakai sehingga diharapkan terjadi peningkatan kinerja. Oleh sebab itu, diperlukan alat bantu sebagai pengolah data yang cepat dan akurat berupa 
komputer yang telah terbukti dapat meminimalisir kelemahan yang ada pada sistem manual. Dengan pemanfaatan yang tepat dan dimaksimalkan, otomatis kinerja tiap individu pengguna sistem informasi berbasis komputer akan dapat meningkat.

Beberapa perusahaan menunjukkan pemanfaatan teknologi informasi pada perusahaan dapat meningkatkan produktifitas pekerjanya. Hal ini sebagian dapat dilihat dari pemakaian staff yang lebih lama waktu yang digunakan di depan komputer (Santoso, 2005). Penelitian yang dilakukan Ahearne dan Schillewaerth (2003) dalam Santoso (2005) mengungkapkan dampak dari teknologi informasi positif pada kinerja karyawan. Kemajuan teknologi yang memanfaatkan sistem informasi berbasis komputer dalam pekerjaan sehari-hari akan dapat mendorong para individu untuk kinerja serta layanan kepada customers secara optimal. Berdasarkan uraian tersebut, maka hipotesis dirumuskan sebagai berikut :

$\mathrm{H}_{2}$ : Penggunaan Teknologi Informasi berpengaruh positif terhadap kinerja individual.

Pemakai sistem informasi akuntansi sangat mempengaruhi proses kegiatan operasional perusahaan karena merupakan hal yang penting untuk memberikan keunggulan kompetitif di masa yang akan datang. Pemahaman, penggunaan dan pengaplikasian sebuah teknologi menjadi sebuah informasi yang berguna akan membuat kinerja sistem informasi berjalan dengan baik sehingga perusahaan dapat mengambil keputusan dan tujuan perusahaan dapat tercapai. Dalam mengembangkan sistem informasi diperlukan kemampuan individu dalam menguasai teknik pengggunaan sistem informasi agar dapat menghasilkan sebuah informasi yang berguna dan dapat menciptakan laporan yang akurat. Sistem 
Putu Maya Fransisca Rahayu dan I Dewa Gede Dharma Suputra. Pengaruh...

informasi akuntansi akan berjalan dengan baik jika karyawan sebagai pengguna sistem informasi harus mampu menguasai teknik penggunaan sistem berbasis komputer agar dapat memproses sejumlah transaksi dengan cepat, menyimpan dan mengambil data dalam jumlah yang besar sehingga dapat mengurangi kesalahan numerik dan dapat menghasilkan laporan yang tepat waktu dan akurat (Setyawan, 2013).

Hasil penelitian Aditya dan Suardikha (2013) menyatakan bahwa keahlian para pengguna komputer dan kenyamanan fisik tidak mampu meningkatkan pengaruh tingkat efektivitas sistem informasi akuntansi terhadap kinerja karyawan. Hasil penelitian oleh Widyasari (2015) menunjukkan bahwa terdapat pengaruh positif antara kemampuan pemakai sistem informasi akuntansi terhadap kinerja individual. Berdasarkan uraian tersebut, maka hipotesis dirumuskan sebagai berikut :

$\mathrm{H}_{3}$ : Kemampuan teknik pemakaimemoderasi pengaruh penggunaan sistem informasi akuntansi terhadap kinerja individual.

Teknologi informasi digunakan untuk meningkatkan kinerja individu di perusahaan karena akan mempermudah kegiatan operasional dalam penerapan sistem informasi akuntansi (Baig dan Gururajan, 2011). Individu akan menggunakan teknologi untuk membantu mereka dalam meningkatkan kinerja (Goodhue dan Thompson, 1995). Teknologi informasi berpengaruh terhadap keberadaan informasi akuntansi karena sistem dapat dikembangkan dengan menggunakan teknologi informasi menggunakan informasi akuntansi guna membantu kegiatan audit serta pengolahan data akuntansi (Darono, 2009). 
Teknologi informasi digunakan untuk mengolah dan menyimpan data, serta mengirimkannya dalam berbagai bentuk yang memungkinkan serta berbagai cara guna menghasilkan manfaat yang berarti bagi para pemakainya. Informasi berkualitas yang diharapkan dapat membantu pihak yang berkepentingan dalam mengidentifikasi masalah maupun menyelesaikannya serta dapat melakukan evaluasi atas hasil atau pencapaian perusahaan.

Pada hubungan penggunaan teknologi informasi dengan kinerja perusahaan, peneliti mengacu pada hasil penelitian oleh Suratini (2015), menunjukkan adanya pengaruh positif signifikan antara penggunaan teknologi informasi terhadap kinerja individual. Kemampuan individu dalam penggunaan teknologi informasi dapat memperkuat maupun memperlemah hubungan dari kemampuan teknik pemakai sistem informasi akuntansi terhadap penggunaan teknologi informasi dan pengaruhnya terhadap kinerja individual. Berdasarkan uraian tersebut, maka hipotesis dirumuskan sebagai berikut :

$\mathrm{H}_{4}$ : Kemampuan teknik pemakai memoderasi pengaruh penggunaan informasi terhadap kinerja individual.

\section{METODE PENELITIAN}

Penelitian ini merupakan penelitian kuantitatif yang berbentuk asosiatif serta mengandung dugaan adanya hubungan antar variabel penelitian dalam populasi yang akan diuji melalui hubungan antar variabel dalam sampel. Model yang diuji pada penelitian ini adalah pengaruh penggunaan sistem informasi akuntansi dan penggunaan teknologi informasi pada kinerja individual yang dimoderasi oleh kemampuan teknik pemakai SIA. Penelitian ini dilakukan pada koperasi simpan 
Putu Maya Fransisca Rahayu dan I Dewa Gede Dharma Suputra. Pengaruh...

pinjam di Kota Denpasar yang telah menerapkan sistem informasi akuntansi untuk mengolah data akuntansinya dan telah tercatat di Dinas Koperasi Kota Denpasar. Obyek dalam penelitian ini adalah pengaruh penggunaan sistem informasi akuntansi, penggunaan teknologi informasi, kemampuan teknik pemakai dan kinerja individual pada koperasi simpan pinjam di Kota Denpasar. Data primer diperoleh dari jawaban responden terhadap pernyataan kuesioner yang dikumpulkan dari koperasi simpan pinjam di Kota Denpasar. Data sekunder dalam penelitian ini brupa data mengenai daftar koperasi simpan pinjam di Kota Denpasar. Metode pengumpulan data yang digunakan dalam penelitian ini adalah dengan wawancara dan kuisioner.

Populasi dalam penelitian ini adalah seluruh koperasi simpan pinjam yang berada di Kota Denpasar yaitu sebanyak 209 Koperasi Simpan Pinjam (Dinas Koperasi, UKM Kota Denpasar, 2016).

\section{Tabel 1.}

Jumlah Koperasi Simpan Pinjam di Kota Denpasar

\begin{tabular}{cc}
\hline Kecamatan & $\begin{array}{c}\text { Jumlah } \\
\text { (Unit) }\end{array}$ \\
\hline Denpasar Barat & 52 \\
Denpasar Selatan & 65 \\
Denpasar Timur & 49 \\
Denpasar Utara & 43 \\
\hline Total & $\mathbf{2 0 9}$ \\
\hline Sumber :Dinas Koperasi, UKM Kota Denpasar, 2016.
\end{tabular}

Sampel dalam penelitian ini diambil menggunakan teknik purposive sampling dengan kriteria pengambilan sampel adalah karyawan pengguna sistem informasi akuntansi pada koperasi simpan pinjam di Kota Denpasar yang telah 
bekerja lebih dari satu tahun. Pemilihan responden pada penelitian ini dilakukan dengan memilih pegawai yang secara langsung menggunakan sistem informasi akuntansi diantaranya adalah kepala/manajer, bagian pembukuan dan kasir. Metode pengumpulan data yang digunakan dalam penelitian ini adalah metode wawancara dan kuisioner.

Teknik analisis data dalam penelitian ini dilakukan dengan pengujian instrumen berupa uji validitas dan uji reliabilitas terlebih dahulu. Kemudian dilakukan uji asumsi klasik yang terdiri dari uji normalitas dan uji heteroskedastisitas. Teknik analisis koefisien regresi dalam penelitian ini menggunakan uji Moderating Regression Analysis (MRA) yang merupakan aplikasi khusus mengandung unsur interaksi yaitu perkalian dua atau lebih variabel independen (Liana, 2009). Pengujian interaksi inilah yang digunakan menguji hubungan antara penggunaan sistem informasi akuntansi dan teknologi informasi terhadap kinerja individual dengan kemampuan teknik pemakai digunakan sebagai variabel pemoderasi. Persamaan statistik yang digunakan adalah

$$
Y=\alpha+\beta_{1} X_{1}+\beta_{2} X_{2}+\beta_{3} X_{3}+\beta_{4} X_{1} X_{3}+\beta_{5} X_{2} X_{3}+\varepsilon
$$

Keterangan :

$\begin{array}{ll}\mathrm{Y} & =\text { Kinerja individual } \\ \alpha & =\text { Konstanta } \\ \beta_{1}, \beta_{2}, \beta_{3} \beta_{4} & =\text { Koefisien } \\ \mathrm{X}_{1} & =\text { Penggunaan sistem informasi akuntansi } \\ \mathrm{X}_{2} & =\text { Penggunaan teknologi informasi } \\ \mathrm{X}_{3} & =\text { Kemampuan teknik pemakai SIA } \\ \mathrm{e} & =\text { Standard Error }\end{array}$


Putu Maya Fransisca Rahayu dan I Dewa Gede Dharma Suputra. Pengaruh...

\section{HASIL DAN PEMBAHASAN}

Instrumen berupa kuisioner digunakan dalam penelitian ini dengan kepala/ manajer koperasi simpan pinjam, karyawan bagian pembukuan dan kasir di koperasi simpan pinjam di Kota Denpasar sebanyak 93 orang sebagai sampel penelitian. Kuisioner disebar pada 40 koperasi simpan pinjam yang ada di Kota Denpasar. Uraian tersebut dapat dilihat dalam data Tabel 2.

Pada Tabel 2. terlihat bahwa sebanyak 120 eksampler kuisioner disebar dalam penelitian ini. Sebanyak 93 kuisioner yang dikembalikan oleh responden. Kuisioner yang tidak kembali adalah sebanyan 18, hal ini terjadi dikarenakan kuesioner masih belum terisi karena adanya kesibukan dari pegawai sampai batas waktu yang ditentukan.

Tabel 2.

Data Penyebaran dan Pengembalian Kuesioner

\begin{tabular}{lr}
\multicolumn{1}{c}{ Uraian } & $\begin{array}{c}\text { Jumlah } \\
\text { Kuisioner }\end{array}$ \\
\hline Total kuisioner yang disebar & 120 \\
Kuisioner yang tidak kembali & 18 \\
Kuisioner yang dikembalikan & 93 \\
Kuisioner yang dibatalkan & 9 \\
Kuisioner yang digunakan dalam analisis & 93 \\
\hline Tingkat Pengembalian (Respon Rate) = 93/120x100\% & $7,75 \%$ \\
\hline Tingkat pengembalian yang digunakan (Usable Response & $7,75 \%$ \\
Rate) & \\
\hline
\end{tabular}

Sumber: Data Diolah, 2018

Karakteristik responden merupakan profil dari 93 responden yang berpartisipasi dalam pengisian kuesioner penelitian ini dengan responden yaitu kepala/manajer koperasi simpan pinjam, bagian pembukuan, dan kasir koperasi. Karakteristik responden dapat dilihat pada Tabel 3. 
Tabel 3. menunjukkan bahwa karakteristik responden berdasarkan jenis kelamin dapat digunakan untuk mengetahui proporsi responden laki-laki dan perempuan pada koperasi simpan pinjam di Kota Denpasar. Jumlah responden laki-laki sebanyak 37 orang $(39,78 \%)$ dan jumlah responden perempuan sebanyak 56orang $(60,22 \%)$.

Responden yang berusia $<20$ tahun sebanyak 7 orang $(07,53 \%)$, 21 sampai 25 tahun sebanyak 18 orang (19,35\%), usia 26 sampai 30 tahun sebanyak 10 orang (10,75\%), usia 31 sampai 35 tahun sebanyak 18 orang $(19,35 \%)$, dan sebanyak 40 orang yang berusia lebih dari 35 tahun (43,02\%). Responden dengan tingkat pendidikan pada jenjang SMP sebanyak 1 orang $(01,08 \%)$, SMA sebanyak 58 orang $(62,36 \%)$, pada jenjang Diploma sebanyak 5 orang $(05,38 \%)$, pada jenjang S1 sebanyak 27 orang $(29,03 \%)$ dan responden yang memiliki pendidikan pada jenjang S2 sebanyak 2 orang $(02,15)$. Sebanyak 12 orang $(12,90 \%)$ yang bekerja antara satu sampai dua tahun. Sebanyak 20 orang $(21,51 \%)$ yang bekerja selama dua sampai tiga tahun, dan 61 orang $(65,59 \%)$ yang bekerja selama lebih dari tiga tahun.

Tabel 3.

Karakteristik Responden

\begin{tabular}{llcc}
\hline Karakteristik & Jumlah & $\begin{array}{c}\text { Persentase } \\
(\boldsymbol{\%})\end{array}$ \\
\hline Jenis Kelamin: & 37 & 39,78 \\
Laki-laki & 56 & 60,22 \\
Perempuan & 93 & 100 \\
Total & & \\
Umur: & 7 & 07,53 \\
< 20 Tahun & 18 & 19,35 \\
21-25 Tahun & 10 & 10,75 \\
26-30 Tahun & 18 & 19,35 \\
31-35 Tahun & 40 & 43,02 \\
>35 Tahun & 93 & 100 \\
Total & & \\
\hline
\end{tabular}




\begin{tabular}{lcc}
\hline Tingkat Pendidikan: & - & - \\
SD & 1 & 01,08 \\
SMP & 58 & 62,36 \\
SMA & 5 & 05,38 \\
D & 27 & 29,03 \\
S1 & 2 & 02,15 \\
S2 & 93 & 100 \\
Total & & \\
Pengalaman Kerja: & & \\
1 - 2 tahun & 12 & 12,90 \\
- 3 tahun & 20 & 21,51 \\
3 tahun & 61 & 65,59 \\
Total & 93 & 100 \\
\hline
\end{tabular}

Sumber : Data diolah, 2018

Berdasarkan Tabel 4. diketahui bahwa seluruh indikator pernyataan dalam variabel kinerja individual, efektivitas sistem informasi akuntansi, penggunaan teknologi informasi dan kemampuan teknik pemakai sistem informasi akuntansimemiliki koefisien korelasi yang lebih besar dari 0,3. Jadi, seluruh indikator telah memenuhi syarat validitas data. Seluruh instrumen penelitian yang digunakan yaitu variabel penggunaan sistem informasi akuntansi, penggunaan teknologi informasi dan kemampuan teknik pemakai sistem informasi akuntansi memiliki koefisien Cronbach'c Alpha $\geq$ dari 0,60 sehingga dapat disimpulkan bahwa pernyataan pada kuesioner tersebut reliabel.

Tabel 4.

Hasil Uji Validitas dan Reabilitas

\begin{tabular}{clccccc}
\hline No & Variabel & Pernyataan & $\begin{array}{c}\text { Korelasi } \\
\text { Item } \\
\text { Total }\end{array}$ & $\begin{array}{c}\text { Keteranga } \\
\text { n }\end{array}$ & $\begin{array}{c}\text { Cronbach } \\
\text { Alpha }\end{array}$ & $\begin{array}{c}\text { Keteranga } \\
\text { n }\end{array}$ \\
\hline 1 & Penggunaan & X1.1 & 0,603 & Valid & & \\
& SIA (X1) & X1.2 & 0,675 & Valid & & \\
& & X1.3 & 0,583 & Valid & & \\
& & X1.4 & 0,623 & Valid & & \\
& & X1.5 & 0,708 & Valid & 0,901 & Reliabel \\
& & X1.6 & 0,757 & Valid & & \\
& & X1.7 & 0,573 & Valid & & \\
& & & & &
\end{tabular}




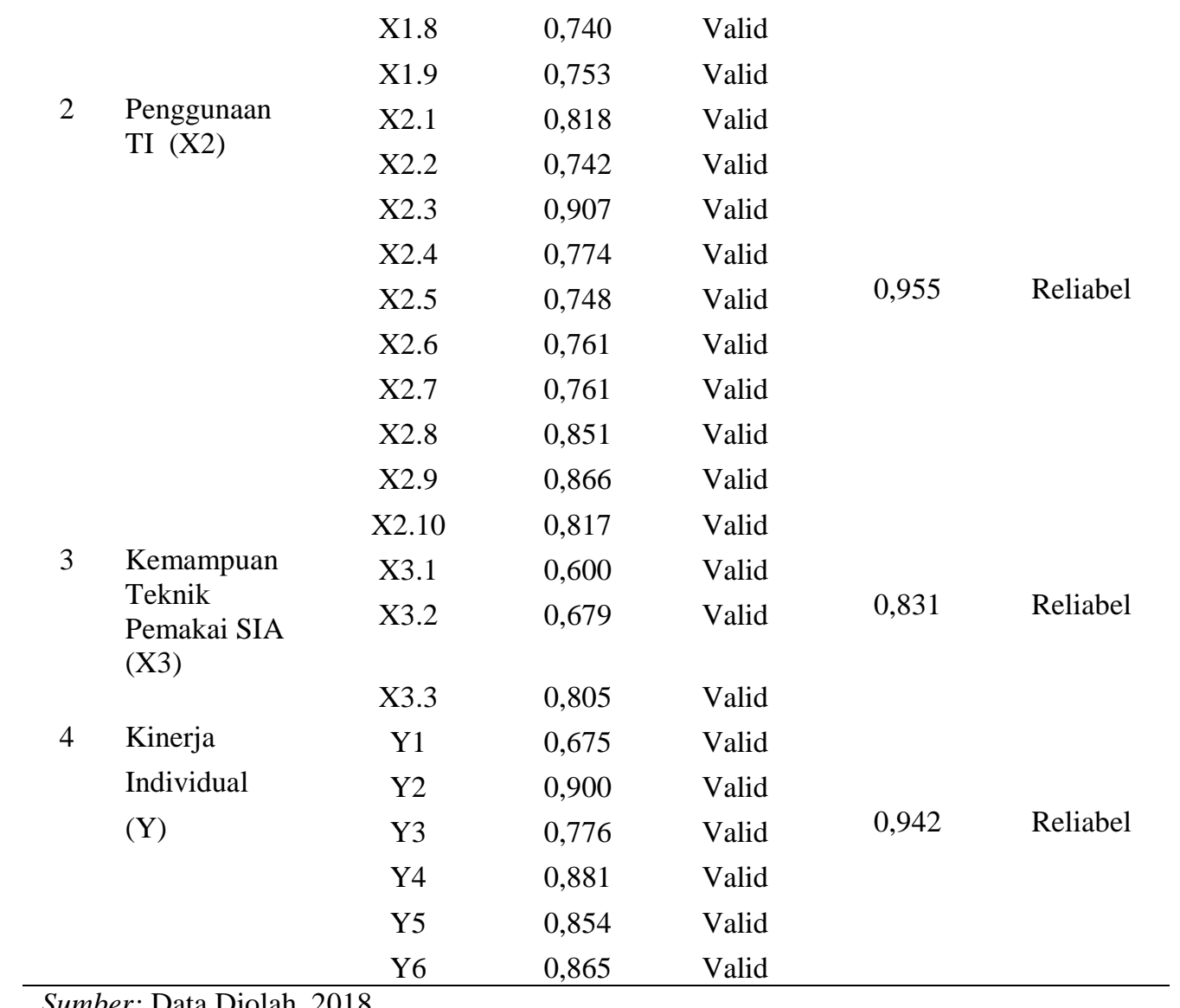

Tabel 5. menunjukkan bahwa nilai terendah dari jumlah skor jawaban responden untuk variabel penggunaan sistem informasi akuntansi $\left(\mathrm{X}_{1}\right)$ adalah 10,44 nilai tertinggi 34,98 dengan nilai rata-rata 26,6981 dan nilai standar deviasi 6,76772. Nilai terendah dari jumlah skor jawaban responden untuk variabel penggunaan teknologi informasi $\left(\mathrm{X}_{2}\right)$ adalah 10,00 nilai tertinggi 38,51 dengan nilai rata-rata 30,1510 dan nilai standar deviasi 8,27626. Nilai terendah dari jumlah skor jawaban responden untuk kemampuan teknik pemakai sistem informasi akuntansi $\left(\mathrm{X}_{3}\right)$ adalah 3,00 nilai tertinggi 11,12 dengan nilai rata-rata 8,8937 dan nilai standar deviasi 2,73982. Nilai terendah dari jumlah skor jawaban responden untuk variabel kinerja individual (Y) adalah 6,00 nilai tertinggi 22,21 dengan nilai rata-rata 17,6700 dan nilai standar deviasi 5,33295. 
Tabel 5.

Hasil Uji Statistik Deskriptif

\begin{tabular}{|c|c|c|c|c|c|}
\hline Variabel & ] & in. $^{M}$ & ax. $^{\text {M }}$ & ean $^{M}$ & $\begin{array}{r}\text { Std. } \\
\text { Deviasi }\end{array}$ \\
\hline \begin{tabular}{l}
\multicolumn{1}{c}{ Penggunaa } \\
n Sistem Informasi \\
Akuntansi (X1)
\end{tabular} & 3 & $\begin{array}{r}10 \\
, 44\end{array}$ & $\begin{array}{r}3 \\
4,98\end{array}$ & $\begin{array}{r}2 \\
6,6981\end{array}$ & 6,76772 \\
\hline $\begin{array}{l}\text { Penggunaa } \\
\text { n Teknologi } \\
\text { Informasi (X2) }\end{array}$ & 3 & $\begin{array}{r}10 \\
, 00\end{array}$ & $\begin{array}{r}3 \\
8,51\end{array}$ & $\begin{array}{r}3 \\
0,1510\end{array}$ & 8,27626 \\
\hline $\begin{array}{l}\quad \text { Kemampua } \\
\text { n Teknik } \\
\text { Pemakai(X3) }\end{array}$ & 3 & $\begin{array}{c}3, \\
00\end{array}$ & $\begin{array}{r}1 \\
1,12\end{array}$ & $\begin{array}{r}8, \\
8937\end{array}$ & 2,73982 \\
\hline $\begin{array}{r}\text { Kinerja } \\
\text { Individual }(\mathrm{Y})\end{array}$ & 3 & $\begin{array}{c}6, \\
00\end{array}$ & $\begin{array}{r}2 \\
2,21\end{array}$ & $\begin{array}{r}1 \\
7,6700\end{array}$ & 5,33295 \\
\hline
\end{tabular}

Hasil uji normalitas pada Tabel 6. menunjukkan angka yang lebih besar dari 0,05 yaitu nilai koefisien Asymp. Sig (2-tailed) adalah sebesar 0,062. Hal ini menunjukkan bahwa data dalam penelitian ini berdistribusi normal. Hasil uji heteroskedastisitas variabel $\mathrm{X}_{1}$ sebesar 0,398 , nilai variabel $\mathrm{X}_{2}$ sebesar 0,484 dan nilai variabel $\mathrm{X}_{3}$ sebesar 0,162 hal tersebut menunjukkan besar nilai sig. pada masing-masing variabel berada di atas 5 persen $(0,05)$ sehingga dapat ditarik kesimpulan bahwa model regresi yang digunakan bebas heteroskedastisitas. 
Tabel 6.

Hasil Uji Asumsi Klasik

\begin{tabular}{|c|c|c|}
\hline & $\begin{array}{r}\text { Uji } \\
\text { Normalitas }\end{array}$ & $\begin{array}{c}\text { Uji } \\
\begin{array}{c}\text { Heteroskedastisi } \\
\text { tas }\end{array} \\
\end{array}$ \\
\hline Parameter Yang Diuji & $\begin{array}{l}\text { Asymp. } \\
\text { Sig. } \\
\text { (2- } \\
\text { tailed) }\end{array}$ & Sig. \\
\hline Unstandarized Residual & 0,062 & \\
\hline $\begin{array}{l}\text { Penggunaan Sistem } \\
\text { Informasi Akuntansi (X1) }\end{array}$ & & 0,398 \\
\hline $\begin{array}{l}\text { Penggunaan Teknologi } \\
\text { Informasi (X2) }\end{array}$ & & 0,484 \\
\hline $\begin{array}{l}\text { Kemampuan Teknik } \\
\text { Pemakai Sistem Informasi } \\
\text { Akuntansi (X3) }\end{array}$ & & 0,162 \\
\hline
\end{tabular}

Berdasarkan Tabel 7. dapat disusun persamaan regresi sebagai berikut:

$\mathrm{Y}=1,129+0,041 \mathrm{X}_{1}+0,369 \mathrm{X}_{2}-0,067 \mathrm{X}_{3}+0,043 \mathrm{X}_{1} \mathrm{X}_{3}-0,020 \mathrm{X}_{2} \mathrm{X}_{3}+\mathrm{e}$

Nilai konstanta sebesar 1,129 mengandung arti bahwa nilai penggunaan sistem informasi akuntansi, penggunaan teknologi informasi, dan kemampuan teknik pemakai sama dengan nol maka nilai kinerja individual sebesar 1,129 satuan. Nilai koefisien $\beta_{1}=0,041$ memiliki arti jika nilai penggunaan sistem informasi akuntansi bertambah satu satuan, maka nilai dari kinerja individual akan mengalami peningkatan sebesar 0,041 satuan. Nilai koefisien $\beta_{2}=0,369$ memiliki arti jika nilai penggunaan teknologi informasi bertambah satu satuan, maka nilai dari kinerja individual akan mengalami peningkatan sebesar 0,369 satuan. 
Tabel 7.

Hasil Uji Moderating Regression Analysis (MRA)

\begin{tabular}{|c|c|c|c|c|c|}
\hline \multirow{2}{*}{ Variabel } & \multicolumn{2}{|c|}{$\begin{array}{l}\text { Unstandardized } \\
\text { Coefficients }\end{array}$} & \multirow{2}{*}{$\begin{array}{c}\text { Standardized } \\
\text { Coefficients }\end{array}$} & \multirow{2}{*}{$\mathbf{t}$} & \multirow{2}{*}{ Signifikansi } \\
\hline & B & Std. Error & & & \\
\hline $\begin{array}{l}\text { (Constant) } \\
\text { Penggunaan }\end{array}$ & 1,129 & 2,815 & & 0,401 & 0,689 \\
\hline $\begin{array}{l}\text { SIA (X1) } \\
\text { Penggunaan }\end{array}$ & 0,041 & 0,110 & 0,052 & 0,369 & 0,713 \\
\hline $\begin{array}{l}\text { TI (X2) } \\
\text { Kemampuan }\end{array}$ & 0,369 & 0,103 & 0,573 & 3,592 & 0,001 \\
\hline Teknik (X3) & $-0,067$ & 0,490 & $-0,034$ & $-0,137$ & 0,892 \\
\hline X1_X3 & 0,043 & 0,016 & 0,842 & 2,696 & 0,008 \\
\hline $\begin{array}{l}\text { X2_X3 } \\
\text { Adjusted R } \\
\text { Square }\end{array}$ & $-0,020$ & 0,012 & $-0,473$ & $-1,647$ & 0,103 \\
\hline F hitung & 73,561 & & & & \\
\hline Signifikansi F & 0,000 & & & & \\
\hline
\end{tabular}

Nilai koefisien $\beta_{3}=-0,067$ memiliki arti jika nilai kemampuan teknik pemakai sistem informasi akuntansi berkurang satu satuan maka nilai dari kinerja individual akan mengalami penurunan sebesar 0,067 satuan. Nilai koefisien $\beta_{4}=$ 0,043 mengandung arti jika kemampuan teknik pemakai sistem informasi mampu memoderasi pengaruh penggunaan sistem informasi akuntansi terhadap kinerja individual. Semakin baik kemampuan teknik pemakai sistem informasi akuntansi maka akan mempengaruhi hubungan penggunaan sistem informasi akuntansi terhadap kinerja indovidual. Nilai koefisien $\beta_{5}=0,020$ mengandung arti jika kemampuan teknik pemakai sistem informasi mampu memoderasi pengaruh penggunaan teknologi informasi terhadap kinerja individual. Semakin baik kemampuan teknik pemakai sistem informasi akuntansi maka akan mempengaruhi hubungan penggunaan teknologi informasi terhadap kinerja 
individual. Kenaikan dan penurunan nilai diasumsikan akan terjadi jika variabel bebas lainnya dalam penelitian ini konstan.

Nilai koefisien regresi variabel penggunaan sistem informasi akuntansi adalah 0,041 hal ini berarti terdapat pengaruh positif penggunaan sistem informasi akuntansi pada kinerja individual sehingga hipotesis $\mathrm{H}_{1}$ diterima dalam penelitian ini. Tingkat penggunaan sistem informasi akuntansi yang semakin tinggi dalam sebuah organisasi maka kinerja individual juga akan semakin meningkat. Koperasi simpan pinjam yang menerapkan sistem informasi akuntansi dan dapat menggunakan sistem tersebut dengan baik serta dapat memanfaatkan teknologi informasi secara efektif maka hal tersebut akan meningkatkan kinerja individual para pegawai sebagai pengguna sistem sehingga dapat menghasilkan informasi yang akurat dan tepat waktu. Hasil penelitian ini sejalan dengan hasil penelitian sebelumnya yang dilakukan oleh Marlita dan Dharmadiaksa (2014), Aditya (2015) dan Suratini (2015) menyatakan bahwa efektivitas sistem informasi akuntansi berpengaruh positif dan signifikan terhadap kinerja individual.

Nilai koefisien regresi variabel penggunaan teknologi informasi adalah 0,369 hal ini berarti terdapat pengaruh positif penggunaan teknologi informasi pada kinerja individual sehingga hipotesis $\mathrm{H}_{2}$ diterima dalam penelitian ini. Tingkat penggunaan teknologi infomasi yang semakin tinggi akan berpengaruh terhadap kefektifitasan kinerja individual karena dengan adanya teknologi informasi akan mempermudah dan memperlancar proses pengerjaan tugas individu sehingga menjadi lebih efektif dan efisien, oleh karena itu kinerja individual juga akan semakin meningkat. Hal ini sesuai dengan penelitian yang 
Putu Maya Fransisca Rahayu dan I Dewa Gede Dharma Suputra. Pengaruh...

dilakukan oleh Chandra (2008) yang diperoleh adanya pengaruh signifikan variabel penggunaan teknologi informasi terhadap evaluasi kinerja individual dan Penelitian Goodhue dan Thompson (1995) memberikan bukti empiris bahwa terdapat pengaruh pemanfaatan teknologi informasi terhadap kinerja individual.

Nilai koefisien regresi interaksi antara penggunaan sistem informasi akuntansi dengan kemampuan teknik pemakai sistem informasi akuntansi adalah 0,043 hal ini berarti terdapat pengaruh positif kemampuan teknik pemakai sistem informasi akuntansi pada hubungan penggunaan sistem informasi akuntansi terhadap kinerja individual sehingga hipotesis $\mathrm{H}_{3}$ diterima dalam penelitian ini. Hal ini menunjukkan bahwa semakin baik kemampuan pengguna sistem maka sistem informasi akuntansi akan mudah diterapkan sehingga penggunaan sistem informasi akan meningkat pula dan berdampak pada kinerja individual yang semakin meningkat karena kegiatan operasianalnya dipermudah denga adanya sistem informasi akuntansi dalam sebuah organisasi. Sistem informasi akuntansi akan sangat efektif jika pemakai sistem memiliki kemampuan untuk memahami, menguasai, mengaplikasikan dan menggunakan teknologi informasi dengan baik dan benar yang secara langsung dapat meningkatkan kinerja individual sehingga tujuan perusahaan dapat tercapai.

Hasil penelitian ini sejalan dengan yang hasil penelitian oleh Al-eqab and Adel (2013) yang menyatakan bahwa pengguna sistem informasi akuntansi seperti manajemen puncak artinya pemakai sistem yang memilki kemampuan untuk menguasai teknologi informasi berada dalam posisi yang lebih unggul dibandingkan dengan yang tidak memiliki kemampuan menguasai teknologi, 
karena mereka akan memahami dengan baik sebuah desain sistem informasi akuntansi dan kemudian dapat menggunakan pengetahuan dan pemahaman mereka untuk merencanakan pengembangan sebuah sistem dengan mencocokkan informasi yang mereka butuhkan sehingga sistem akan berjalan dengan efektif.

Nilai koefisien regresi interaksi antara penggunaan teknologi informasi dengan kemampuan teknik pemakai sistem informasi akuntansi adalah 0,020 hal ini berarti terdapat pengaruh kemampuan teknik pemakai sistem informasi akuntansi pada hubungan penggunaan teknologi informasi terhadap kinerja individual sehingga hipotesis $\mathrm{H}_{4}$ diterima dalam penelitian ini. Kemampuan individu dalam penggunaan teknologi informasi dapat memperkuat maupun memperlemah hubungan dari kemampuan teknik pemakai sistem informasi akuntansi terhadap penggunaan teknologi informasi dan pengaruhnya terhadap kinerja individual. Semakin baik kemampuan penggunaan teknologi informasi akan mempengaruhi teknik pemakai sistem informasi dalam memahami dan menguasai sistem tersebut dikarenakan sebelum memahami cara penggunaan sebuah sistem individu dituntut untuk memiliki kemampuan dalam menggunakan teknologi informasi. Berdasarkan hal tersebut maka dengan adanya sistem informasi akuntansi yang mampu digunakan karena individunya paham akan teknik penggunaan teknologi maupun sistem tersebut akan meningkatkan pengaruh kinerja individual pada organisasi

\section{SIMPULAN}

Berdasarkan hasil penelitian yang telah diuraikan pada bab sebelumnya maka dapat ditarik simpulan dalam penelitian ini adalah penggunaan sistem informasi 
Putu Maya Fransisca Rahayu dan I Dewa Gede Dharma Suputra. Pengaruh...

akuntansi berpengaruh positif pada kinerja individual koperasi simpan pinjam di Kota Denpasar. Penggunaan teknologi informasi berpengaruh positif pada kinerja individual koperasi simpan pinjam di Kota Denpasar. Semakin meningkatnya penggunaan informasi akuntansi dengan teknologi informasi akan mempermudah kegiatan bisnis di dalam organisasi sehingga kinerja individual akan semakin meningkat. Kemampuan teknik pemakai sistem informasi akuntansi mampu memoderasi pengaruh penggunaan sistem informasi akuntansi pada kinerja individual koperasi simpan pinjam di Kota Denpasar. Kemampuan teknik pemakai sistem yang semakin baik akan meningkatkan penggunaan sistem informasi akuntansi sehingga memperpudah kegiatan operasional yang secara langsung meningkatkan kinerja individual. Kemampuan teknik pemakai sistem informasi akuntansi mampu memoderasi pengaruh penggunaan teknologi informasi pada kinerja individual koperasi simpan pinjam di Kota Denpasar. Semakin baik kemampuan teknik pemakai sistem informasi dalam memahami dan menguasai cara penggunaan sebuah teknologi informasi maka akan meningkatkan pengaruh kinerja individual pada organisasi.

Berdasarkan hasil penelitian dan simpulan yang diperoleh, maka saran yang dapat yaitu dengan terbuktinya pengaruh penggunaan sistem informasi akuntansi dan penggunaan teknologi informasi terhadap kinerja individual, maka hasil penelitian ini diharapkan dapat memberikan masukan kepada pihak-pihak yang terkait dalam hubungan dengan kinerja individual. Penggunaan teknologi memberikan pengaruh terhadap peningkatan kinerja individual, jadi sebaiknya koperasi-koperasi simpan pinjam di Kota Denpasar memberikan pendidikan dan 
pelatihan terlebih dahulu kepada masing-masing individu, khususnya yang mempergunakan komputer untuk mempermudah karyawan dalam menyelesaikan tugasnya. Anggota koperasi simpan pinjam di Kota Denpasar diharapkan untuk terus melakukan evaluasi terhadap sistem informasi akuntansi yang digunakan guna menyesuaikan dengan perkembangan jaman dan kebutuhan informasi sehingga dapat memberikan pelayanan jasa keuangan yang dapat bersaing dan memiliki keunggulan kompetitif.

\section{REFERENSI}

Aditya, I Gede Mahendra dan Ni Luh Sari Widhiyani. 2016. Kemampuan Teknik Pemakai Memoderasi Pengaruh Efektivitas Sistem Informasi Akuntansi Pada Kinerja Individual Koperasi Simpan Pinjam di Kecamatan Tabanan.EJurnal Akuntansi Universitas Udayana,15(3), pp: 1886-1912.

Alannita, Ni Putu dan Suaryana, Gusti Ngurah Agung. 2014. Pengaruh Kecanggihan Teknologi Informasi, Partisipasi Manajemen, dan Kemampuan Teknik Pemakai Sistem Informasi Akuntansi Pada Kinerja Individu. E-JurnalAkuntansi Universitas Udayana, 6(1), pp: 33-45.

Aditya,Puja Pratamadan Suardikha, I Md. Sadha. 2013. Keahlian Pemakai Komputer dan Kenyamanan Fisik Memoderasi Pengaruh Efektivitas Sistem Informasi Akuntansi Terhadap Kinerja Karyawan di PT. Bank Sinar Harapan Bali Denpasar. E-Jurnal Akuntansi Universitas Udayana, 5(2), pp: 361-381.

Al Eqab, Mahmod dan Dalia Adel. 2013. The Impact of IT Sophisticutions on the Perceived Usefulnes Of Accounting Information Characteristics among Jordanian Listed Companies. International Jurnal of Business and SocialScience. 4(3), pp: 143-155.

Al-hiyari, Ahmad. 2013. Factors that Affect Accounting Information System Implementation and Accounting Information Quality: A Survey in University Utara Malaysia. American Journal of Economics 2013, 3(1), pp: 27-31.

Baridwan, Zaki. 2009. Sistem Informasi Akuntansi. Edisi keenam. Yogyakarta: BPFE-UGM. 
Putu Maya Fransisca Rahayu dan I Dewa Gede Dharma Suputra. Pengaruh...

Baswir, Revrisond. 2010. Koperasi Indonesia. Yogyakarta: BPFE Yogyakarta.

Bodnar, George H and Hopwood, William S. 2006. Sistem Informasi Akuntansi, Edisi ke-9. Yogyakarta: Andi.

Chendi Antasari, Kadek dan Pt D’yan Yaniartha. 2015. Pengaruh Efektivitas Sistem Informasi Akuntansi dan Penggunaan Teknologi Informasi Pada Kinerja Individual dengan Kepuasan Kerja sebagai Variabel Pemoderasi. EJurnal Akuntansi Universitas Udayana, Vol 10.2,hal: 354-369.

Cragg, Paul., Annette, and Theek. 2010. Understand IT Management and UKM. Journal Sistem Informasi University of Canterbury, Christchurch, New Zaeland. 13(1), pp: 27-34.

Dinas Koperasi dan UKM Kota Denpasar. 2016. Laporan Tahunan. Tabanan.

Edison, G., Manuere, F, Joseph, M., and Gutu, K. 2012. Evaluation of Factors Influencing Adoption of Acounting Informasi by Small to Medium Enterprises in Chinhoyi. Journal of Contemporary Research in Bussiness, 4(6), pp: 1126-1141.

Ghozali, Imam. 2011. Aplikasi Analisis Multivariate dengan Program IMB SPSS19. Edisi Kelima. Semarang: Badan Penerbit Universitas.

Goodhue, D.L dan Thompson, R.L, (1995). “Task-Technology Fit and Individual Performance.” MIS Quarterly, (19:2), pp.213-236.

Grande, Elena Urquia. 2011. The Impact of Accointing Information System (AIS) on Performance measures: Empirical evidence in Spanish SMEs1. JournalInternational of Digital Accounting Research.11(2), pp:25-43.

Hall, James. A. 2009. Sistem Informasi Akuntansi. Edisi Keempat. Jakarta: Salemba Empat.

Indriantoro, N. dan Supomo, B. 2013.Metodologi Penelitian Bisnis. Yogyakarta: BPFE.

Ismail, N. A. \& King, M. 2007. Factors Influencing the Alignment of Accounting Information System in Small and Medium Sized Malaysian Manufacturing Firm. Journal of Information System and Small Business, 1(1/2), pp: 1-19.

Jogiyanto. 2000. Sistem Informasi Berbasis Komputer, Edisi ke-2, BPFE, Yogyakarta.

Jusuf, Al Haryono. 2011. Dasar-Dasar Akuntansi. Jilid I. Edisi, Ketujuh. 
Yogyakarta: YKPN.

Kusumastuti, M. Cherta, dan Irwandi, S. Agus. 2012. Investigasi Empat Faktor Kontigensi sebagai Variabel Moderating Terhadap Partisipasi Pemakai dan Kepuasan Pemakai dalam Pengembangan Sistem Informasi. Jurnal AkuntansiFakultas Ekonomi STIE Parbanas, 2(2), pp:139-150.

Liana, Lie. 2009. Penggunaan MRA dengan SPSS untuk Menguji Pengaruh Variabel Moderating terhadap Hubungan Antara Variabel Independen dan Variabel Dependen. Jurnal Teknologi Informasi DINAMIK, 14(2), pp: 9097.

Maamir, Christine Iryani dan Yadnyana, I Ketut.2012. Pengaruh Efektivitas Penggunaan dan Kepercayaan pada Teknologi Sistem Informasi Terhadap Kinerja Individual di PT PLN (Persero) Distribusi Bali Area Pelayanan Denpasar.E-Jurnal Akuntansi Universitas Udayana.

Mollanazari, M. \& Abdolkarimi, E. 2012. The Influence Task, Organizational and Accounting Information System on The Performance Characteristics of Accounting Information System in Tehran Stock Exchange. Journal International of Innovation, Management and Technologi. 3(4), pp: 443448.

Naniek Noviari. 2007. "Pengaruh Kemajuan Teknologi Informasi terhadap Perkembangan Akuntansi”. Jurna Akuntansi dan Bisnis. Vol 2, Nol.

Onaolopo, A. A and Odetayo T. A. 2012. Effect of Accounting Information System on Organisational Effectiveness: A Case Study of Selected Construction Companies in Ibadan, Nigeria. American Journal of Business and Management. 1(4). pp: 183-189.

Ridwan dan Engkos Ahmad Kuncoro. 2007. Cara Menggunakan dan Membaca Analisis Jalur (Path Analysis). Bandung: CV Alfabeta.

Salehi, Mahdi; Rostami Vahab; Mogadam Abdolkarim.2010. Usefulness of Accounting Information System in Emerging Economy: Empirical Evidence of Iran. International Journal of Economics and finance. pp: 186-195.

Sari, Maria. M. Ratna. 2009. Pengaruh Efektivitas Penggunaan dan Kepercayaan Terhadap Teknologi Sistem Informasi Akuntansi Terhadap Kinerja Individu pada Pasar Swalayan di Kota Denpasar. Jurnal Ilmiah Akuntansi dan Bisnis. 4(1).Sugiyono. 2014. Metode Penelitian Bisnis. Bandung: Alfabeta.

Turban, Rainer dan Potter. 2006. Pengantar Teknologi Informasi. Jakarta: Salemba Infotek. 